Meta

Journal des tradlucteurs

Translators' Journal

\title{
Who's afraid of Henry Calvin?
}

\section{Cliff Hanley}

Volume 27, numéro 2, juin 1982

URI : https://id.erudit.org/iderudit/003003ar

DOI : https://doi.org/10.7202/003003ar

Aller au sommaire du numéro

Éditeur(s)

Les Presses de l'Université de Montréal

\section{ISSN}

0026-0452 (imprimé)

1492-1421 (numérique)

Découvrir la revue

Citer cet article

Hanley, C. (1982). Who's afraid of Henry Calvin? Meta, 27(2), 185-188.

https://doi.org/10.7202/003003ar d'utilisation que vous pouvez consulter en ligne.

https://apropos.erudit.org/fr/usagers/politique-dutilisation/ 


\section{Who's afraid of Henry Calvin ?*}

Cliff Hanley

The title of my paper is reasonably cryptic. Somebody else chose it. Let me warn you at once that this essay may be less authoritative than many others in our séance. I have been the subject of translation, but in academic terms I am hardly an expert. I am more of a specimen than an operator.

The title should be explained. My name is Clifford Hanley, and I have written a dozen books and innumerable other things under that name. I have also written a dozen romans policiers under the name of Henry Calvin. This may be a peculiarly Scottish thing; the urge to hide behind another personality. Sir Walter Scott started his career with careful anonymity as "the author of the Waverley novels". One of our great novelists of this century, Lewis Grassic Gibbon, was actually James Leslie Mitchell. Our outstanding poet, Hugh McDiarmid, was a man called Christopher Grieve.

These, I suppose, are forms of translation.

A few years ago, almost by accident, I also became Ebenezer Mcllwham, an elusive character who called himself the Bard of Whifflet West, and produced verses in the dense and incomprehensible patois known as Scots.

There are three languages in my native country. One is English. Let's call it Standard English, at the risk of offending any diachronic linguists in the audience. As a diachronic linguist, I have never hesitated to offend diachronic linguists. Another is Gaelic, which has no close kinship with English at all, being a member of the Goedelic group. It is spoken by a small group of people in the Highlands and the Islands.

And, in the lowlands, there is Scots. Scots IS a version of English. It shares the grammar and much of the vocabulary. It is not a VARIANT of EnglishEnglish. It is itself. In the centuries when England and Scotland were politically and economically separate, Scots-English developed its own ground rules, retained and developed its own lexis.

Scotland is a small country. Therefore Scots is a minority tongue; as are Dutch and Danish.

Minority tongues, like minority cultures, are under constant pressure from their majority neighbours. We can see here a vague analogy with French in Canada.

But the Scottish case is particular. Early in the $17^{\text {th }}$ century, the crowns of England and Scotland were united under one king - a Scotsman, who lost no time

* Colloque de Glendon, 1980. 
in rushing to London, where the action was. He ordered an English translation of the Bible, which was and remains a great work of literature; English-English literature.

The Scots of the time were passionate Christians and theologians. The new English Bible hurled them into schizophrenia.

It was there, not in Latin but in the vernacular, and could be read by Everyman. What happened was that educated Scotsmen realised that while they discussed everyday matters, like farming and weaving, and cooking, and sex, in Scots, God spoke English.

Englishmen have always known that, of course. After all, God wasn't a foreigner. A Jew, yes, but an English-speaking Jew.

The resultant trauma has been one of the sad and hilarious elements in Scottish linguistic history since. Our national poet, Robert Burns, by simple genius, restored the Scots language to respectability two centuries ago. But polite Scots remembered Robert Burns once a year, on his birthday, read his poems at drunken suppers, and then nagged their kids for using Burnsian language on any other day.

It is hardly twelve years since I myself was dropped from a radio programme in Glasgow, Scotland, because a couple of dozen Scottish listeners complained about my non-English accent and my use of low-class Scottish words. Oh, the shame of being provincial, of not being metropolitan English! Of not talking like Laurence Olivier!

My friend Doctor David Murison, who has recently completed his life work of compiling the National Dictionary of the Scottish Language, always felt urgent, in a hurry, because he was convinced that within a generation the whole vocabulary of Scots would vanish under the impact of English Government and English-Controlled television; and that very soon an educated Scot would be unable to read his national poet without a gloss.

I venture to think Doctor Murison may be wrong.

In the few years since the British Broadcasting Corporation, in Scotland, brought undying shame on itself by giving me the boot - and partly because of that act of moral idiocy - there has been a renaissance of enthusiasm for the old Scots tongue. The language is alive, and well, and very difficult.

One of the great difficulties is encountered by English authors who create Scottish characters - usually for a laugh - and get it all wrong, so that all their contemporary Scottish characters sound like the late Sir Harry Lauder, and say Hooch aye the Noo, and Beggin' your parrrdon, surrrr, ye canna bang a saxpence out of a wee sporrrrran, a hundred pipers an" a' an a', ye ken. Harry Lauder made it up as he went along; for money.

The genuine Scots tongue is not so easily acquired. Curiously enough, its vocabulary owes something to French, since for centuries there was an alliance between France and Scotland against England, the Old Enemy. In Scots, a piedish is an ashet. We have gigot chops, unknown to the English. When we describe a girl as DOUCE, any Francophone would understand. A Scottish house, or a man, or a village, may be BIEN. These and many other Scots words are legacies of the old alliance. 
On the other hand, Scots has retained words and pronunciations from Old English which have vanished in modern English-English. Let me write some Scottish numbers: ane, twa three, fower, five, sax, seeven. You can see the echo of an earlier Germanic source.

In the First World War, when a Scottish regiment was billeted in France, a resourceful private reported to his comrades, "It's easy to get two eggs from the old farmer round the corner. You just say Twa Oofs, he gives you three eggs and you give him one back."

The Scots vocabulary persists, and thrives, in the demotic tongue. As I have said, some of it is the survival of older English forms. When a Scotsman says oxter, for instance, he means armpit. He is not trying, and failing, to pronounce armpit. He could say armpit if he felt like it. If a Scottish child complains that his jaurie has run along the cyber and varnished down a stank, he means that his marble has rolled in the gutter and fallen through a grating. He is not mispronouncing anything. He is speaking his own language, clearly and understandably.

I am trying to distinguish here between pronunciation, which is the inalienable right of any local group; and vocabulary, which is the same inalienable right.

If we hear a Cockney Englishman say Dahn ve ill, we know he is trying to say down the hill; and indeed, he IS saying down the hill, as long as the other Cockney he is speaking to understands that. Language is a simple matter of a speaker being understood by his listener.

But if a Scot says doon the brae, he is NOT trying to say down the hill. He is saying doon the brae. Brae, (hill) is one of the small number of Gaelic words that have crept into Lowland Scots. Hill, in Gaelic, is bruaich.

In a way, I can sympathise with all those outraged radio listeners who objected to my Scottish usages. After all, this is the civilised twentieth century, we are all British, and it's time we got homogenised. Minority tongues are a damned nuisance whether they are ours or somebody else's. Let's all speak proper, like God, and get rid of those stupid variations. (Do I strike a chord among any Canadien-français?)

And when it comes to pronunciation pure and simple, the Glasgow Scot can be a nuisance. Here is a Glasgow dialogue. Wherr urry? Erry ur ower err. Where are they? There they are over there. Où se trouvent-ils? Les voilà, là-bas. Is there perhaps some region in France, or in French-Canada, where a proper French speaker could find a similar confusion? I am sure there is. I was fascinated, as a student of French, to hear a boat-hirer many miles south of Paris quote quaratta frah as the cost per hour. (I speak French, this man speaks gibberish.)

As an ignorant amateur, I have always been puzzled by the fact that our great-grandmother tongue, Indo-European, was highly structured, conjugated and declined, and that as its children developed, they got looser and more flexible. I would have imagined the reverse procedure - starting simple, and getting complicated. I am ignorant. But I observe, I am even capable of learning.

If a highly developed language is one which has got looser, and more flexible, and farther and farther away from precision and more into poetry, then Scots is one of the great developments of Indo-European. 
A snatch of verse from that contemporary Scottish bard.

There was yince a Kate McCurdy

A sonsie-lukkin' burdie

Was the dochter o' a bowly-leggit lairdie

She was smit by Cupid's arra

When she trippit ower a barra

And the gairdner picked her up and gie'd her bairdie.

What does it mean? It means something to the Scots. It is a piece of language. Let me now say that I have a besotted reverence for English, the tongue that Shakespeare spoke. I have had a lifelong love affair with French. We have not always understood each other, but that is what love affairs are about. I cling to what German and Spanish and Italian I know, I enjoy having a few dozen words of Finnish. I am not really a chauvinist, I could not be the simple sergeant who says My general right or wrong.

Language is a high blood-pressure subject, because it is ingrained in us, like sex. When we try to look at it objectively, we are like a man with a microscope, which can certainly help us to study a microbe, but which cannot be used to examine itself. In looking at language, we are looking at it WITH language.

What matters is that we should realise exactly that, and realise that people inside other languages are in the same position. As fast as society, and myopic governments, try to homogenise and standardise language (as well try to standardise the weather) human beings, the true creators of language, are finding new variations, new words, new languages, even. Is it not staggering to think that all the seven and seventy jarring European tongues developed in a mere five thousand years? The process certainly can't be over.

But we are here, today, in our own time; with our own languages. This is, in the end, a moral lecture. We may respect, we may learn to like or even love, other people's tongues when we have come to terms, with, and acquired a love for, our own.

The Anglophone who despises French, or Russian, or Chinese, is a man who does not appreciate English.

I am probably excessively honoured in being asked to contribute to this colloquium. But if I have little experience of translation, I have feelings about it. It involves technique. We can't play the piano with expression and subtlety until we have mastered the brute business of hitting the right notes; and we can't translate until we have acquired the painful process of knowing the words and the syntax. But beyond the technique and above the technique, there is something crucial and essential; and it starts with our own language, however bizarre (as mine is).

I suppose it's something like love. 